\title{
THE UNTOLD TRUANCY STORIES: A CASE STUDY IN MALAYSIA
}

Tai Soo Shong ${ }^{1}$, PhD, Lecturer, Department of English, Institute of Teacher Education Tengku Ampuan Afzan Campus, 27200 Kuala Lipis, Pahang Darul Makmur, Malaysia.

(miel_de_montagne@yahoo.com)

Siti Hajar Abu Bakar Ah, PhD, Associate Professor, Department of Social Administration and Justice, Faculty of Arts and Social Sciences, University of Malaya, 50603 Kuala Lumpur, Malaysia.

(shajar@um.edu.my)

\section{Abstract}

This collective qualitative case study explored the truancy experiences of six habitual truants between the ages of 13-17 who reside in an Approved School in Kuala Lumpur. The purpose of this study was to examine the kind of activities that these habitual truants used to participate so as to gain a deeper insight into their lifestyle, behavioural patterns, and living habits as well as the seriousness of truancy. The researcher used the purposive sampling strategy in the selection of the six participants. The data generation methods used in this study include interviews, observations, and document analysis. The findings that emerged from this study showed that these habitual truants used to skip classes, sneak out of the school, stay out late, and look for ways to make money during school hours, take drugs, steal, rob, break into shops or houses, and waste their time hanging around looking for mischief. All these antisocial activities eventually caused them to end up as school failures and landed them in the juvenile school.

Keywords: truancy, antisocial behaviour, mischief, theft, loafing, prevention.

\footnotetext{
${ }^{1}$ Corresponding author
} 


\section{Introduction}

The word 'truancy' may have different meanings to different people as there is no standardised definition for truancy. It originated from the 12th Century old French word 'trougant' meaning beggar, vagabond, or rogue, and the Welsh used the word to mean wretch or wretched (Shute \& Cooper, 2015). Stoll (1990 cited in Amuso, 2007) defined truancy as "absence from school for no legitimate issues" (p.17). However, the extent of absence may range from milder cases such as skipping classes to more serious ones such as absences of several days or even weeks or months.

\section{Literature Review}

Studies have indicated that chronic truancy may be a precursor to school failure, dropping out of school, antisocial behaviour and more serious offending in adulthood (Zhang, Katsiyannis, Barrett, \& Wilson, 2007; Zhang, Willson, Katsiyannis, \& Jiun, 2010; Monahan, VanDerhei, Bechtold, \& Cauffman, 2014) and this applies particularly to the males (Loeber \& Farrington, 2000b).

Students do not regularly play truant from school without reasons as truancy may also signify that the students involved are in trouble and need of help (Thornton, Darmody, \& McCoy, 2013). Students who feel bored at school and who are always having problems trying to catch up with their lessons often have the tendency to be truant (Vaughn, Maynard, Salas-Wright, Perron, \& Abdon, 2013; Tollit, 2014; Shute \& Cooper, 2015).

Similarly, poor classroom management, poor relationships with teachers and peers, poor support from teachers, as well as disrespect from teachers may also induce chronic absenteeism amongst the students (Attwood \& Croll, 2006; Gonzales, Richards, \& Seeley, 2002; Breda, 2014; Havik, Bru, \& Ertesvåg, 2015; Rasasingham, 2015; Şahin, Arseven, \& Kılıç, 2016).

Harsh and irrational disciplinary actions at school may also cause the students to resort to truancy as a means of escape from the painful realities of school life (Breda, 2014). Lack of parental supervision is another contributing factor as parents who have no knowledge of their children's whereabouts and activities often produce truant children (Vaughn, Maynard, Salas-Wright, Perron, \& Abdon, 2013; Rasasingham, 2015; Şahin, Arseven, \& Kilıç, 2016). 
Since children who play truant from school have the tendency to spend time with kids like themselves, this can sometimes lead to risk taking behaviour (Henrich, Brookmeyer, Shrier, \& Shahar, 2006). The saying that 'birds of a feather flock together' does have its significance since the peer groups formed by truant students may do more harm than good. It is within these groups that they learn the art of crime as they continue to influence one another in a negative way. Hochstetler, Heith and Matt (2002) said that "Interaction with deviant peers results in cognitive changes that make offending more attractive" (p.559).

As proposed by the Social Learning Theory (Akers, 2009), adolescents with constant exposure to deviant behaviour "in early life on a relatively frequent basis over a long period of time and from sources they like or respect" (Agnew \& Cullen, 2003, p.125) are at a higher risk for antisocial behaviour. Mingling with truant peers and participating in their antisocial activities can shape children views towards those adopted by their peers (Bronfenbrenner \& Morris, 1998; Kindermann, 2007, 2008; Kindermann \& Gest, 2009). As children mingle with their truant peers, their perceptions and attitudes towards life also change to suit the needs and aspirations of their peer groups thus resulting in more refine antisocial behaviour.

Truancy often acts as a precursor for behavioural problems and early school leaving (Witte \& Csillag, 2012). As a risk factor for crime and delinquency, truancy is often related to a whole host of antisocial behaviours such as bullying, dropping out of school, suicide, premature sexual activity, gangsterism, substance abuse, drug trafficking, vandalism, theft, burglary, robbery, gang fights, and even murder (Chang \& Romero, 2008; Henry \& Huizinga, 2007; Loeber \& Farrington, 2000a).

Truancy has always been a serious problem in many Malaysian schools since many Malaysian students have the habit of staying away from school during school hours without good reasons. It is a social ill that cannot be taken lightly as this would mean that the students would not only lag behind in their lessons but may also drop out of school eventually since dropping out is always easier than going back to school.

Dropping out of school would also mean that "they are more likely to gravitate toward unstructured socialising with peers" and put themselves "at greater risk of involvement in future criminal acts and substance use" (Sweeten, Bushway, \& Paternoster, 2009, p.59). As they are trying "to set themselves up for a life of struggle" (US Department of Education, 1996, p.1), their 
opportunities for career advancement is greatly reduced due to their low education level (Carlson, 2014; Attwood \& Croll, 2015).

\section{Methodology}

In 2009, a qualitative study was conducted with a primary objective to examine the truancy experiences of six habitual truants in a juvenile school in Kuala Lumpur to gain a deeper insight into their lifestyle, behavioural patterns, and living habits as well as the seriousness of truancy. The findings that emerge could generate ideas that would enable the researchers to come out with the necessary suggestions and recommendations for truancy prevention and control.

\section{Research approach and design}

A qualitative case study was preferred as the design enabled the researcher to capture a rich source of first-hand information that comes from the words of the participants (Miles \& Huberman, 1994). The researcher has also generated in-depth data through observations, field notes, and the review of the participants' personal files.

\section{Sampling technique and sample of the study}

Purposive sampling was used in this study for the selection of colourful cases to be studied intensively to discover the real-life experiences of truant students. This method of sampling is particularly suited for the phenomenon under investigation since the purpose of the researcher was to explore, understand, and gain insight of the cases at hand and therefore had to select a sample that could provide the researchers with the most information (Merriam \& Tisdell, 2016). Since studying the entire population of truant students is impossibility, a purposive sample is selected to accurately represent the population under investigation to meet the objectives of the survey.

The participants of this study were 4 Malay boys, 1 Chinese boy, and 1 Indian boy between the ages of 13-17 who reside in a juvenile school in Kuala Lumpur. All of them come from poverty-stricken families with parents who lack proper parenting skills. Two of them are from single-mother families while one of them has been rejected by his parents all his life. All of them had no interest in their studies and performed badly at school. Information about their age, race, religion, the crime they have committed, their parents' occupation and marital status are summarised in Table 1. 
Table 1: Respondents' Profiles

\begin{tabular}{|ccccccl|}
\hline Name & Gender & Age & $\begin{array}{c}\text { Race/ } \\
\text { Religion }\end{array}$ & $\begin{array}{c}\text { Crime } \\
\text { Committed }\end{array}$ & $\begin{array}{c}\text { Parents' } \\
\text { Marital } \\
\text { Status }\end{array}$ & Parental occupation \\
\hline Ariffin & M & 13 & $\begin{array}{c}\text { Malay / } \\
\text { Islam }\end{array}$ & Theft & Separated & Mother - hawker / part- \\
time tailor.
\end{tabular}

\section{Data generation methods}

The data generation methods include the individual in-depth structured, semistructured, and unstructured interviews to capture the words and voices of the participants. The interviews were audio-taped and immediately transcribed so as to preserve its originality. The researcher also took written notes during each interview but these were limited so that they could focus more on the participants. Interviews that were conducted originally in Malay or Chinese were translated into English without losing their original meanings. The study also involved the direct observations method; where the researchers were personally involved with the participants throughout the data generation process. Another technique is document analysis i.e. the analysis of the personal files of the participants.

\section{Data analysis technique}

The data generated was categorized through the identification of themes or patterns that cut across the lives of the participants (Lapadat, 2010, p.296). This method of data analysis provided a detailed insight into the similarities and differences of the participants' behaviour, lifestyle, and experiences which were coded and categorised by the themes or patterns that emerged.

\section{Ethical considerations}

Prior to the commencement of data generation, the researcher has obtained written permission from the Social Welfare Department, Malaysia; as well as 
the Research Monitoring Unit of the University of Malaya. Written consent from the participants as well as the principal of the juvenile school also was obtained. The researcher uses pseudo names to protect the identity of the respondents.

\section{Results and Discussion}

The study revealed that truant students have the habit of skipping classes, sneaking out of school, making money during school hours, staying out late, loafing, taking drugs, and committing theft-related offences. All these activities have proven to be detrimental not only to their well-being, character, and behavioural development but also to society. Each of these themes is discussed in greater depths in the following sections.

\section{Skipping classes}

Skipping classes in this study is taken to mean spending time in empty classrooms, school toilet, canteen, or any well-hidden place within the school compound. It is perhaps the mildest of all truancy activities as the students are still in school. However, students who skip classes are often involved in some mischief in school which may be detrimental not only to themselves but other students as well.

According to Irwan, for instances, he and his schoolmates would sometimes skip classes and hang around somewhere near the hall. Ariffin and his school mates were no exceptions as they were also doing what Irwan and his schoolmates were doing. Instead of whiling away their time near the hall, they prefer to smoke in empty classrooms. Zulkifli and his friends, on the other hand, would hang around in the backyard of the school while Loga preferred to sit in the canteen and pretended to be sick each time he was caught. Apart from whiling away his time with his classmates near the hall, Irwan would sometimes hide in the school toilet to extort money from his schoolmates to increase his pocket money. The same applied to Syazwan and Zulkifli who would beat up their school mates whenever they refused to give them money. Although Ariffin and his school mates did not extort money from anyone, they would take whatever they could from the school bags whenever they found no one in the classrooms. Needless to say, after skipping classes for some time and seeing that it was good, they became even more daring and started playing truant from school. In a way, it may also be true to say those students who play truant from school would also skip classes as well when they are at school. Below are examples of verbatim about this matter. 
I played truant from school many times... after that even if I went to school also I skipped classes... hanging around near the hall with my friends... 21 of them...

(Irwan/Juv/10/Sch)

My pocket money is actually not enough. I need to pay RM2 for petrol when I go to school. My father only gave me RM2. That was why I did not eat at school. That was why I sat in the toilet to ask for money from other students.

(Irwan/Juv/03-04/Sch)

\section{Sneaking out of school}

Sneaking out of school refers to the situation where the students are present at school for some time and then leave the school secretly by jumping over the back gate or simply walking out of the front gate without being interrupted by the guard on duty. Jumping over the back gate was nothing new to Loga during his primary school days. He would jump over the back gate whenever he felt like it and went to the nearest cyber café with his truant schoolmates:

I followed my friends... they invited me... so I followed them to play truant from school went to CC. I followed them... they said jump over the gate and go... I jumped over the gate and go ahh.

(Loga/Juv/06/Pee)

He would sometimes meet his mother on his way to the cyber café but since she did not seem to mind, he was happy doing what he wanted to do. He would also take his bag and rush out of the school immediately to go to the cyber café each time after being caned by his teachers:

They asked me to lie down... like the prison style. They caned anywhere liked. After that, I took my bag and walked off. I said to them, you caned anywhere you liked, I go anywhere I like. I walked to the back of the school, jumped over the gate and went to $C C$.

(Loga/Juv/07/Sch) 
Like Loga, Ah Fook also had the habit of sneaking out of school but not through the back gate. All he had to do was to walk past the guard house at the front gate as the guards on duty did not seem to mind at all:

I played truant mostly in form 1. One god sister asked me to play truant. After playing truant once, I found it very enjoyable so I played truant again and again. The guard couldn't be bothered when he saw me walking out of the school.

(AhFook/Juv/08-09/Sch)

Being frugal in his expenditure, Ah Fook did not like the idea of wasting his money in the cyber cafés. He preferred to spend his precious time 'fishing' in one of the shopping complexes instead:

I've got reason. I wanted to make money. I went 'fishing' at Mutiara Kompleks and made a lot of money. I won many tokens that can be exchanged for money at the counter. My parents know that I don't like to study. They know that I like to make money.

(AhFook/Juv/08/Sch)

As his parents and teachers did nothing to stop him, he carried on with his truancy activities boldly, walking out of his school compound whenever he felt like doing so without the slightest tinge of remorse.

\section{Working during school hours}

Working during school hours refers to the situation where the students play truant from school with the intention to increase their pocket money by doing some kind of job. To increase his pocket money, Ah Fook worked part-time in a bakery after school at first. Lacking interest in his studies, he decided to absent himself from school as often as he could and worked for longer hours:

No matter how hard I study, my brain cannot absorb it. It's like forcing a piece of thick wood into a small hole. Impossible, isn't it? Unless, they (my parents) put the dictionary inside my brain. What do they think I am? Robot ah? If I don't study, I can still learn a skill and become a boss. Those who study in the university can only earn RM2000-RM3000 per month.

(AhFook/Juv/06/Sch) 
Prolonged absence from school has killed whatever interest he has left in his studies and taking advantage of his teachers' suggestion that he should stay away from school for some time to reflect on his behaviour, he decided to stop schooling altogether (at the age of thirteen) and worked like an adult. However, not long after that, he was caught by the police in a gang fight involving his triad members and sent to the juvenile school.

\section{Staying out late}

Many school children would agree that staying out late to have fun with peers is always more enjoyable than going to bed early. However, "the later children stay out at night without supervision the more likely they are to associate with a community's worst-behaved, least-supervised kids. And the more time children spend with these kids, the more likely they are to emotionally bond with them and take on their characteristics, values, and behaviour patterns" (Bodenhamer, 1995, p.156). Through peer associations, truant students will influence each other in a negative way (Veronneau \& Dishion, 2010). Irwan, for instance, liked to roam the streets with his truant schoolmates and participated in all their mischiefs late into the night. As a consequence of his late-night activities, he was apprehended by the police in the wee hours of the morning for breaking into a sundry shop in the village after consuming alcohol. Like Irwan, Zulkifli also had a penchant for breaking into the shops in his village, particularly after midnight. Breaking into shops in the wee hours of the morning has also become one of the routine activities for Syazwan and four of his classmates. Apart from breaking into shops, Syazwan and his classmates also had the habit of robbing passers-by in the darkness of the night. To prevent themselves from being discovered by the villagers, they had to cover up their face with a mask each time they went out to rob.

\section{Interviewer: Where did you normally go to steal?}

Syazwan: Stole at... sundry shops, boutiques, buildings... like... handphones, bags

Interviewer: How did you get inside?

Syazwan: Through the roof or pane.

Interviewer: What time did you normally go out to steal?

Syazwan: At 1, 2, 3 a.m.

Syazwan/Juv/09-10/Fam) 
Although Ah Fook does not have the habit of stealing or robbing anyone in the darkness of the night, his late-night activities may sometimes involve gang clashes as he travels from one place to another with his gang members in the middle of the night looking for mischief:

\author{
Interviewer: Did you go out until very late at night? \\ Ah Fook: 1.00 or 2.00 a.m. Sometimes 3.00-4.00 a.m. There were \\ times when I went to Genting Highlands and arrived \\ home at 3-4 a.m. When I am tired of Genting \\ Highlands, I go to Kajang to visit friends.
}

(AhFook/Juv/10-11/Pee)

Needless to say, children who spend time away from home late into the night and in the wee hours of the morning are most likely to get involved in some kind of antisocial activities. This clearly explains why Ah Fook was caught by the police in the wee hours of the morning.

Late nights can have adverse effects on the students' academic performance as they are left with very little time for school work and revision. Having insufficient sleep would also affect their health negatively making them unable to focus on their studies. Children who stay out late would also find it too tiring to attend school the following day and this clearly explains for their habit of skipping school.

Irwan, for instance, had the habit of sleeping in class whilst Syazwan, Zulkifli, and Ah Fook preferred to absent themselves from school altogether after their exciting late night activities. This clearly explains for their poor school performance. Continuous absenteeism has also resulted in Syazwan's expulsion from school and that provided even more opportunities for him to offend until he was apprehended by the police a few months later.

\title{
Substance abuse
}

Truancy has always been associated with substance abuse as truant students are more likely to take drugs than those who attend school regularly (Henry, 2010; Flaherty, Sutphen, \& Gretchen, 2012; Henry, Knight, \& Thornberry, 2012). Syazwan, for instance, would while away his time at the snooker centres and cyber cafés with his peers whilst playing truant from school. That was also how he picked up his drug habit: 
Invited me to go to snooker, $C C .$. began to change there... wanted to get drugs... after that they taught me... to take drugs. After that I wanted to get money... did all sorts of things... robbed, broke into shops.

(Syazwan/Juv/08/Pee)

Once he became addicted to drugs, his attendance at school deteriorated even further as he had to hide away somewhere to take drugs and rob or break into shops in order to get the money to pay for his drugs. Zulkifli and Loga, who did not like the idea of going to school, also shared the same plight as Syazwan as they were encouraged to take drugs by their friends whilst hanging around doing nothing. Once they became addicted to drugs, they had to resort to all sorts of antisocial activities in order to get the money to pay for their drugs.

\section{The 'Lepak' (Loafing) Culture}

Playing truant from school is one haven for many school children as it is only then that they could have the freedom to do whatever they wish to do and indulge in activities that are forbidden at home or school such as smoking, drinking alcohol, and visiting the cyber cafés and snooker centres. That is what gives rise to the 'Lepak (Loafing) Culture' which is a common phenomenon amongst truant students since they are free to loiter around and roam the streets at all times:

\section{Interviewer: According to your school report, out of 75 school days, you only came for 25 days. You didn't even come for the extracurricular activities. Where did you go?}

Ariffin: Followed my friends... went loafing... went to snooker.

(Ariffin/Juv/09/Sch)

Loafing is defined by The American Dictionary as "to pass time at leisure; idle" (p.1054). However, the term lepak in the present study does not mean just idling or loitering around since it has a deeper meaning beyond that. It also means going around and looking out for some kind of mischief. Antisocial behaviour is common amongst our lepak candidates as it is when they are hanging around with their friends that they come up with all sorts of creative ideas to perform some kind of illegal activities in their attempt to look for excitement. 
Irwan and his friends, for instance, had no intention to break into the village shops when they decided to lepak but the intention to do so suddenly came into their minds whilst they were hanging around doing nothing:

... just hanging around at night... suddenly felt that we could break into shops... just like that. After that, if someone said that... the others also supported him... which shop... which shop... they asked.

(Irwan/Juv/12/Pee)

Irwan's 'punk' friends also have the habit to lepak at Bukit Bintang Plaza and this was what they used to do whilst hanging around there:

Ahh... like they saw a handphone or bag... came from behind... just took... and ran. All these happened near Bukit Bintang.

(Irwan/Juv/12/Pee)

His punk friends also encouraged him to take alcohol which is strictly forbidden by his religion. Provocation from his peers left him without a choice as he had to oblige them for fear of offending them:
Ahh... At that time, I had no intention to drink... because at that time we were hanging around... with people who were older than me... with my friends... my friends at Bukit Bintang... the punk kids. While we were hanging around... they drank wine in a cup... we like drank from a cup... in turns. They passed, passed, passed... after that they passed the cup to me. I was afraid to refuse them because if I refuse to drink... they might beat me up or do something to me.

(Irwan/Juv/14/Pee)

The same applied to Zulkifli who had the habit of looking out for some excitement whenever he was hanging around in the village with his peers:

We did what we liked. Saw a house, entered... like feeling bored... went in to watch TV. We treated the house as our own... cooked in the house... ate... what was in the fridge we finished them up... what we wanted, we took. After that, we messed up the house. 
Shop-breaking. I stole like... in this shop, like grocery shop, the shop was already closed at 12, right? I broke into the shop. Usually I took biscuits, crackers, took drinks. There was once, right... I hated the owner of that shop... I broke into his shop, took everything... did not leave anything behind... I took all (laughing). All the cigarettes I took. Felt enjoyable...because my hatred was gone. Not me alone... with kids... 7 of them.

(Zulkifli/Juv/08/Pee)

What Zulkifli meant by 'kids' are school children of his age or to be more exact, his schoolmates. Theft is therefore a natural activity that comes naturally into the minds of our lepak candidates whilst they are hanging around doing nothing and enjoying themselves in the company of their peers.

As for Loga, lepak involves more than just looking out for motorcycles to steal as he may also come across customers who would like to buy his stolen motorcycles:

I did not look for customers. He wanted it. I rode only. I was hanging around... He said he wanted this motor... so I sold it to him. I did not bring it to another place to sell. I brought it along to hang around with my members... he said he wanted the motor... so I sold it to him.

(Loga/Juv/10/Pee)

Loga did not have to look for motorcycle buyers as he could easily bump into them whilst he was hanging around. Loafing, therefore, provided him with an extra source of income as it helped to facilitate his stolen motorcycle sale business.

Similarly, Ariffin and his friends would hang around in the village to look for mischief whilst playing truant from school. Whenever they came across any bicycle worth stealing, they would dismantle the whole bicycle and sell off its parts. And if they happened to come across anything worth stealing in the cars parked in the village, they would break the windscreen and take whatever they wanted from the cars. On the day Ariffin and his brother were caught by the police, they stumbled upon a donation box (which contained RM17) in the mosque and as they did not see anyone around, they decided to take it. However, their act was discovered by the ustaz (a teacher teaching the Islamic 
religion) who happened to be there and he wanted to teach them a lesson by calling the police.

\section{Truancy Prevention and Control}

Truancy is an indication that something has gone wrong with the students and that they are in dire need of help. Since truancy is consistently linked to dropping out of school (Henry, Knight, \& Thornberry, 2012), unemployment, and criminality (Rouse, 2007), interventions targeting this negative social phenomenon should seek to prevent these negative outcomes by re-engaging the students in their school setting (Fredricks, Blumenfield, \& Paris, 2004; Johnson, Wright, \& Strand, 2012; Kearney \& Graczyk, 2014).

In the fight against truancy, school authorities should take stricter measures to reduce truancy and keep the students in school. This can be achieved if all possible exits in the school are properly guarded. Security guards should not be stationed at the school entrance alone as they should also take the trouble to patrol the school from time to time in order to prevent the students from sneaking out. Teachers ought to be more alert instead of keeping one eye closed to the possibility of truancy amongst their students. They must take action whenever they see their students loitering around the school or sitting in the canteen without any good reasons or if their students have been absent for days instead of ignoring them.

However, although they are supposed to take attendance every lesson, sad to say, some of them would simply tick the names in the attendance list without taking the trouble to find out who are those students present on a particular day but are not in the class. This clearly explains why the participants of this study could hang around in the school and/or sneak out of the school so easily without being discovered! Perhaps it's time that the school principals should look into this matter by doing random checks in the classrooms throughout the day. It is also advisable for the teachers to set up a WhatsApp group to maintain consistent communication with the parents and keep them informed of their children's behaviour.

For the purposes of prevention and control, the researchers strongly recommend the implementation of truancy programs at school. The key to success of implementing truancy programs is to ensure that the children stay in school and stay away from trouble whilst at the same time receive an 
adequate education (Cabus \& Witte, 2015). To enhance the effectiveness of these programs, schools can collaborate with the parents as well as the justice system for better prevention and control of truancy (White, Fyfe, Campbell, \& Goldkamp, 2001; Wright, McMahon, Daly, \& Haney, 2012).

One such truancy program that has proven its effectiveness is the ACT (Abolish Chronic Truancy) Now Program. The purpose of this program is to make the habitually truant students in Arizona return to school and this is achieved through the cooperation of schools, law enforcers and parents (Baker, Sigmon, \& Nugent, 2001). Attendance clerks in the participating schools monitor the students' attendance closely and would send a letter to the parents upon the students' first unexcused absence. In this letter, parents are made aware of their children's unexcused absence and that their children's attendance record would be sent to the Pima County Attorney's Office (PCAO) after their third unexcused absence. Parents are also informed that they themselves stand the possibility of a prosecution if they fail to take any action. Upon the students' third unexcused absence, the students' attendance record, personal data, and any other background information would be sent to the Center for Juvenile Alternatives (CJA) with an affidavit certifying the unexcused absences so as to obviate the necessity of having school officials to testify in court. Upon referral of the case, parents are informed that they may be liable for misdemeanour whilst their children may have to file a truancy petition in a juvenile court. However, the parents are offered the opportunity to participate in a deferred prosecution diversion program that "provides access to counselling, parenting skills classes, and support group for youth and parents" (Baker, Sigmon, \& Nugent, 2001, p.4). The case is dismissed upon successful completion of the program and compliance with the terms of the diversion agreement. On the other hand, parents who refuse to take any actions after being notified of their children's unexcused absences would be prosecuted.

A milder program which has proven its effectiveness in the prevention of truancy is the Truant Recovery Program (White, Fyfe, Campbell, \& Goldkamp, 2001), which is both a school-based cognitive education program as well as a family-based prevention program in Richmond, California. In this program, habitual truants are provided with the necessary life skills whilst their families are provided with the assistance that they need in order to bring about the required attitudinal and behavioural change in their children that could help to deter future truancy. This program also gives the local police to make contact with children who play truant from school during school hours be it on the streets, internet cafes or snooker centres and return them to their parents or school. 
In the above-mentioned truancy programs, one can see that a two-way communication between the settings in which the children and their parents participate such as the home and school (mesosystem) can work wonders in the prevention of truancy (Fagan, 2013; Bronfenbrenner \& Morris, 1998). As such, the researchers strongly recommend that parents should be made accountable for their children's chronic truancy as this can go a long way to curb this negative social phenomenon. This is because many Malaysian parents either have no idea that their children are playing truant from school behind their backs or they do not bother whether their children attend school or not as long as their children do not give them any problems.

Since many children who play truant from school do so with the knowledge of their parents who do not mind them taking a day or two off from school (Sheppard, 2010), which clearly shows that the parents concerned do not consider truancy to be a serious issue. That was probably the reason why the parents scolded one of the researchers when she called to inform them about their children's unexcused absences from school saying that they knew about it and that it did not matter as their children were only resting at home. However, the thought that they have to attend a truancy program if their children play truant from school would certainly make the parents pay more attention to their children's school attendance since many of them cannot afford the time to do so

Since prosecuting the parents for their children's truant behaviour could create havoc amongst Malaysian parents who are not used to being treated in such an insulting manner, the Truant Recovery Program is a more suitable program to be replicated here with some modifications to suit the Malaysian way of life. In Malaysian schools, class teachers are supposed to keep a record of their students' attendance in the register and upon their students' tenth unexcused absence (intermittently), they should send a warning letter to their parents to notify them. If their parents did not take any action, the teachers would send a second and third warning letter to the parents after the $20^{\text {th }}$ and $40^{\text {th }}$ unexcused absences respectively. If the parents still do not take any action after their children's $60^{\text {th }}$ unexcused absence, their children would be expelled from school. However, if the students absent themselves continuously from school, the first warning letter can be issued after three days followed by the second warning letter seven days later and the third warning letter after another seven days. Fourteen days after the issuance of the third warning letter, the students concerned can be expelled from school if they still do not show up. 
Table 2: The Issuance of Warning Letters

\begin{tabular}{|c|c|c|}
\hline Warning Letter & $\begin{array}{l}\text { Intermittent } \\
\text { Absence }\end{array}$ & $\begin{array}{l}\text { Continuous } \\
\text { Absence }\end{array}$ \\
\hline $\begin{array}{l}\text { First Warning } \\
\text { Letter }\end{array}$ & on the tenth day & on the third day \\
\hline $\begin{array}{l}\text { Second Warning } \\
\text { Letter }\end{array}$ & $\begin{array}{l}10 \text { days after first } \\
\text { warning letter }\end{array}$ & $\begin{array}{l}7 \text { days after first } \\
\text { warning letter }\end{array}$ \\
\hline $\begin{array}{l}\text { Third Warning } \\
\text { Letter }\end{array}$ & $\begin{array}{l}20 \text { days after second } \\
\text { warning letter }\end{array}$ & $\begin{array}{l}7 \text { days after second } \\
\text { warning letter }\end{array}$ \\
\hline $\begin{array}{l}\text { Expulsion from } \\
\text { School }\end{array}$ & $\begin{array}{l}20 \text { days after third } \\
\text { warning letter }\end{array}$ & $\begin{array}{l}14 \text { days after third } \\
\text { warning letter }\end{array}$ \\
\hline Total & 60 days & 31 days \\
\hline
\end{tabular}

Once the students are expelled from school, parents can easily apply to the state education department to put their children back in school and this is probably one reason why these warning letters do not have much weight. And of course, one cannot imagine what the students would do during their sixty or thirty-one days of unexcused absences without supervision. To make matters worse, some class teachers do not issue any warning letters to the parents at all even though their students have been absent for months.

A more effective way to deal with truancy is that class teachers should send a warning letter to the parents upon their children's third unexcused absence and if the parents do not take any action and continue to allow their children to play truant from school, the school counsellor should contact them and make them come to school to attend a parenting program in which they are provided with the necessary assistance that they need in order to keep their children at school. At the same time, their children would be sent for counselling so as to bring about some behavioural and attitudinal change in them. And of course, teachers who do not issue warning letters to the parents at the appropriate time should be made answerable to the State Education Ministry for their failure to act.

Schools can also seek the help of the local police to take the students who play truant from school during school hours back to school where disciplinary actions would be taken against them (White, Fyfe, Campbell, \& Goldkamp, 2001). What the researchers mean by disciplinary action is not 
caning as this method of discipline has proven to be ineffective. A more meaningful way of disciplining the students is to make them participate in some kind of service-learning program for 2 weeks after school such as being in charge of the schools' cleanliness or repainting wall murals. The thought of being caught by the police is a disgrace to many Malaysian children and as such they would think twice before they play truant from school. The Rakan COP(Community Orientated Policing) Program has been in operation for some time. The purpose of which is to promote better cooperation between the police, school, and the community for the purposes of more effective truancy prevention. Perhaps it is time for the police to work together more effectively with the schools and the community to solve the problems in relation to truancy.

\section{Conclusion}

This study clearly reveals invaluable information about what is going on in the lives of habitually truant students through their own testimonies. Their untold stories have brought to light the fact that truancy does not simply mean being absent from school as it could lead to a whole host of antisocial activities such as substance abuse, alcohol consumption, criminal damage, gang fights, extortion, robbery, burglary, and many other theft-related offences. As suggested by the researchers, truancy prevention and intervention programs are best carried out through the collaboration of schools, parents, and law enforcers. Given the adverse effects of truancy, it is of utmost importance that these systems should work together to combat this chronic social problem and reduce the dropout rates in our Malaysian schools as well as the juvenile crime rates in this country. It is hoped that this study will inspire policymakers to pass stricter truancy laws and consider the implementation more effective of truancy programs in our Malaysian schools for more effective truancy prevention and control.

\section{References}

Akers, R.L. (2009). Social Learning and social structure: $A$ general theory of crime and deviance. New Brunswick, NJ: Transaction Publishers.

Agnew, R. \& Cullen, F.T. (2003). Criminological Theory: Past to Present (2nd ed.). Los Angeles, CA: Roxbury. 
American Heritage Dictionary (3rd ed.). (1996). Boston, MA: Houghton Mifflin Company.

Amuso, J.G. (2007). The occurrence of student absenteeism from the regular classroom setting and student achievement on the seventh-grade mathematics Mississippi curriculum test (Doctoral dissertation). University of Southern Mississippi, Mississippi.

Attwood, G., \& Croll, P. (2006). Truancy in secondary school pupils: Prevalence, trajectories and pupil perspectives. Research Papers in Education, 21(4), 467484.

Attwood, G., \& Croll, P. (2015). Truancy and well-being among secondary school pupils in England. Educational Studies, 41(1-2), 14-28.

Baker, M.L., Sigmon, J.N., \& Nugent, M.E. (2001). Truancy reduction: Keeping students in school. Juvenile Justice Bulletin. Washington, DC: Office of Juvenile Justice and Delinquency Prevention.

Bodenhamer, G. (1995). Parent in control: Restore order in your home and create a loving relationship with your adolescent. New York, NY: Simon \& Schuster.

Breda, M. (2014). School truancy: Poor school attenders' perceptions of the impact regarding dysfunctional teacher-learner relationships on truant behaviour. Mediterranean Journal of Social Sciences, 5(2), 1056-1063. doi: 10.5901/mjss. 2014.v5n23p1056.

Bronfenbrenner, U., \& Morris, P.A. (1998). The ecology of developmental processes. In W. Damon, \& R.M. Lerner (Eds.), Handbook of child psychology: Theoretical models of human development (5th. ed., Vol. 1, pp. 993-1028). New York, NY: John Wiley \& Sons.

Cabus, S.J., \& Witte, K. (2015). The effectiveness of active school attendance interventions to tackle dropout in secondary schools: A Dutch pilot case. Empirical Economics, 49(1), 65-80. doi: 10.1007/s00181-014-0865-z

Carlson, C.L. (2014). Dropout factories and the vaccination approach: The impact of the dropout rate on the economy and the need for effective literacy instruction. SRATE Journal, 23(2), 1-7. 
Chang, H.N., \& Romero, M. (2008). Present, engaged, and accounted for: The critical importance of addressing chronic absence in the early grades. New York, NY: National Centre for Children in Poverty.

Fagan, A.A. (2013). Family-focused interventions to prevent juvenile delinquency: A case where science and policy can find common ground. Criminology and Public Policy, 12(4), 617-650. doi: 10.1111/1745-9133.12029

Flaherty, C.W., Sutphen, R.D., \& Gretchen, E.E. (2012). Examining substance abuse in truant youths and their caregivers: Implications for truancy intervention. Children \& Schools, 34(4), 201-211. doi: https://doi.org/10.1093/cs/cds008

Fredricks, J.A., Blumenfield, P.C., \& Paris, A.H. (2004). School engagement: Potential of the concept, state of evidence. Review of Educational Research, 74(1), 59-109.doi: 10.3102/00346543074001059

Gonzales, R., Richards, K., Seeley, K. (2002). Youth out of school: Linking absence to delinquency (2nd ed.). Denver, Colorado: The Colorado Foundation for Families and Children.

Havik, T., Bru, E., \& Ertesvåg, S.K. (2015). School factors associated with school refusal and truancy-related reasons for school non-attendance. Social Psychology of Education, 18(2), 221-240. doi: 10.1007/s11218-015-9293-y

Henrich, C.C., Brookmeyer, K.A., Shrier, L.A., \& Shahar, G. (2006). Supportive relationships and sexual behaviour in adolescence: An ecological-transactional approach. Journal of Paediatric Psychology, 31(3), 286-297. doi: 10.1093/jpepsy/jsj024.

Henry, K. (2010). Skipping school and using drugs: A brief report. 17(5), 650657. Drugs: Education, Prevention and Policy, doi: 10.3109/09687630902862452.

Henry, K.L., \& Huizinga, D.H. (2007). School-related risk and protective factors associated with truancy among urban youth placed at risk. Journal of Primary Prevention, 28(6), 505-519. doi: 10.1007/s10935-007-0115-7. 
Henry, K.L., Knight, K.E., \& Thornberry, T.P. (2012). School disengagement as a predictor of dropout, delinquency, and problem substance use during adolescence and early childhood. Journal of Youth and Adolescence, 41(2), 156-166. doi: 10.1007/s10964-011-9665-3

Hochstetler, A., Heith, C., Matt D. (2002). Differential association in group and solo offending. Journal of Criminal Justice, 30(6), 559-566.

Johnson, C.L., Wright, K.A., \& Strand, P.S. (2012). Transitions of truants: Community truancy board as a turning point in the lives of the adolescents. OJJP Journal of Juvenile Justice, 1(2), 34-51.

Kearney, C.A., \& Graczyk, P. (2014). A response to intervention model to promote school attendance and decrease school absenteeism. Child \& Youth Care Forum, 43(1), 1-25. doi: 10.1007/s10566-013-9222-1.

Kindermann, T.A. (2007). Effects of naturally existing peer groups on changes in academic engagement in a cohort of sixth graders. Child Development, 78(4), 1186-1203. doi: 10.1111/j.1467-8624.2007. 01060.x

Kindermann, T.A. (2008). Can we make causal inferences about the influence of children's naturally-existing social networks on their school motivation? In N.A. Card, T.D. Little, \& J.P. Selig (Eds.), Modelling dyadic interdependent data in developmental research, (pp. 343-376). Mahwah, NJ: Erlbaum.

Kindermann, T.A., \& Gest, S.D. (2009). Assessment of the peer group: Identifying naturally occurring social networks and capturing their effects (pp. 100-117). In K. Rubin, W. Bukowski \& B. Laursen (Eds.), Handbook of Peer Interactions: Relationships and Groups. New York, NY: Guilford Press.

Lapadat, J.C. (2010). Thematic Analysis. In A.J. Mills, G. Durepos \& E. Wiebe (Eds.), Encyclopaedia of Case Study Research (pp. 926-928). Thousand Oaks, CA: Sage Publications.

Loeber, R. \& Farrington, D.P. (Eds.). (2000a). Child delinquents: Development, intervention, and service needs. Thousand Oaks, CA: Sage Publications.

Loeber, R. \& Farrington, D.P. (2000b). Young children who commit crime: Epidemiology, development origins, risk factors, early interventions and policy implications. Development and Psychopathology, 12(4), 737-762. doi: $10.1017 /$ S0954579400004107 
Merriam, S.B., \& Tisdell, E.J. (2016). Qualitative research: $A$ guide to design and implementation (4th ed.). San Francisco, CA: Jossey-Bass Publishers.

Miles, M.B., \& Huberman, A.M. (1994). Qualitative data analysis: An expanded sourcebook (2nd ed.). Thousand Oaks, CA: Sage Publications.

Monahan, K.C., VanDerhei, S., Bechtold, J., \& Cauffman, E. (2014). From the school yard to the squad car: School discipline, truancy, and arrest. Journal of Youth Adolescence, 43(7), 1110-1122. doi: 10.1007/s10964-014-0103-1

Ponelis, S.R. (2015). Using interpretative case studies for exploratory research in doctoral studies: A case of informational systems research in small and medium enterprises. International Journal of Doctoral Studies, 10, 535-550.

Rasasingham, R. (2015). The risk and protective factors of school absenteeism. Open Journal of Psychiatry, 5, 195-203.

Rouse, C.E. (2007). Consequences for the labor market. In C.R. Belfield \& H.M. Levin (Eds.), The price we pay: Economic and social consequences of inadequate education (pp.99-124). Washington, D.C.: Brookings Institution Press.

Şahin, Ş., Arseven, Z., \& Kılıı̧, A. (2016). Causes of student absenteeism and school dropouts. International Journal of Instruction, 9(1), 195-210. doi: 10.12973/iji.2016.9115a.

Sheppard, A. (2010). School attendance and attainment: Poor attenders' perceptions of schoolwork and parental involvement in their education. British Journal of Special Education. 36(2), 104-111. doi: 10.1111/j.14678578.2009.00413.x.

Shute, J.W., \& Cooper, B.S. (2015). Understanding in-school truancy: It may not be the student- but the curriculum, teacher, and pedagogy that is perpetuating truancy. Phi Delta Kappan, 96(6), 65-68. doi: 1177/0031721715575303.

Stake, R.E. (1995). The art of case study research. Thousand Oaks, CA: Sage Publications

Sweeten, G., Bushway, S.D., \& Paternoster, R. (2009). Does dropping out of school mean dropping into delinquency? Criminology, 47(1), 47-92. 
Teherani, A., Martimianakis, T., Stenfors-Hayes, T., Wadhwa, A., \& Varpio, L. (2015). Choosing a qualitative research approach. Journal of Graduate Medical Education, 7(4), 669-670. doi: 10.4300/JGME-D-15-00414.1

Thornton, M., Darmody, M., \& McCoy, S. (2013). Persistent absenteeism among Irish primary school pupils. Educational Review, 65(4), 488-501.

Tollit, M.A. (2014). Academic failure, truancy and low school commitment: Patterns, correlates and links with antisocial behaviour during adolescence (Doctoral dissertation). University of Melbourne, Australia.

US Department of Education. (1996). Manual to combat truancy. New Jersey, NJ: SDFS News.

Vaughn, M.G., Maynard, B.R., Salas-Wright, C.P., Perron, B.E., \& Abdon, A. (2013). Prevalence and correlates of truancy in the US: Results from a national sample. Journal of Adolescence, 36(4), 767-776.

Veronneau, M.H. \& Dishion, T. (2010). Predicting change in early adolescent problem behaviour in the middle school years: A meso systematic perspective on parenting and peer experiences. Journal of Abnormal Child Psychology, 38(8), 1125-1137.doi: 10.1007/s10802-010-9431-0

White, M.D., Fyfe, J.J., Campbell, S.P., \& Goldkamp, J.S. (2001). The school-police partnership: Identifying at-risk youth through a truant recovery program. Evaluation Review, 25(5), 507-532. doi: 10.1177/0193841X0102500501.

Witte, K., \& Csillag, M. (2014). Does anybody notice? On the impact of improved truancy reporting on school dropout. Education Economics, 22(6), 549-568

Wright, J.P., McMahon, P.M., Daly, C., \& Haney, J.P. (2012). Getting the law involved: A quasi-experiment in early intervention involving collaboration between schools and the district attorney's office. Criminology \& Public Policy, 11(2), 227-249. doi: 10.1111/j.1745-9133.2012. 0083.x

Zhang, D., Katsiyannis, A., Barrett, D.E., \& Wilson, V. (2007). Truancy offenders in the juvenile justice system: Examination of first and second referrals. Remedial and Special Education, 28(4), 244-256. doi: $10.1177 / 07419325070280040401$ 
Zhang, D., Willson, V.L., Katsiyannis, A., \& Jiun, Y.W. (2010). Truancy offenders in the Juvenile Justice System: A multi cohort study. Behavioural Disorders, 35(3), 229-242. 